\title{
Geochemical Applications of Noble Gases
}

\author{
Tsanyao Frank Yang ${ }^{\mathrm{a} *}$, Bernard Marty ${ }^{\mathrm{b}}$, David R. Hilton ${ }^{\mathrm{c}}$, Mark D. Kurz ${ }^{\mathrm{d}}$ \\ a Department of Geosciences, National Taiwan University, No. 1, Sec. 4, Roosevelt Road, Taipei 106, Taiwan \\ b Centre de Recherches Pétrographiques et Géochimiques, Nancy Unviersité, CNRS, BP 20, 54501 Vandoeuvre les Nancy Cedex, France \\ c Geosciences Research Division, Scripps Institution of Oceanography La Jolla, California 92093-0244, USA \\ d Department of Marine Chemistry and Geochemistry, Woods Hole Oceanographic Institution, MS \#25, Clark Laboratory 421, Woods Hole, MA 02543, USA
}

\begin{abstract}
A B S T R A C T
Noble gases are unique tracers, due to their rarity on Earth and their inertness. Several of their isotopes are produced by nuclear reactions, whereas others were trapped when the Earth formed. They have been widely used for understanding the evolution and structure of the Earth, dating geological events/processes, characterizing magma genesis and volcanism in different tectonic environments, tracing mantle-crust interaction even in non-volcanic areas, and for monitoring earthquake and volcanic activities. Some of these topics were presented at the $9^{\text {th }}$ International Conferences on Gas Geochemistry that was held in 2007 in Taipei, Taiwan. This special volume includes twelve papers, which cover a wide range of applications of noble gases geochemistry such as tracing the thermal evolution of the early Earth, understanding the mantle source of continental basalts, establishing the spatial variations of gas compositions in hot springs and fumaroles from volcanic and forearc areas, as well as in key non-volcanic areas such as faults and seismic zones, tracing the origin and evolution of ore-forming fluids of uranium deposits, reproducing the noble gas behavior during faulting, and, finally, using argon as a tracer of large-scale geologic processes.
\end{abstract}

(c) 2009 Elsevier B.V. All rights reserved.

\section{Introduction}

The $9^{\text {th }}$ International Conference on Gas Geochemistry (ICGG9) was held in Taipei, Taiwan from October $1^{\text {st }}$ to $8^{\text {th }}, 2007$ (Yang, 2008). This conference was a sequel to the last two meetings held in Freiberg, Germany, in 2003 (Heinicke and Martinelli, 2005; Yang et al., 2005), and Sicily, Italy, in 2005 (Boschi et al., 2007; Italiano et al., 2007), respectively. The conference was devoted to all aspects of research and development of gas geochemistry and its applications in the Earth and Planetary Sciences. This meeting brought together leading researchers in the field of gas geochemistry to share their most recent experiences, and advances in analytical techniques and in theoretical modeling to achieve a better understanding of the special role of gases in different terrestrial processes.

In this conference, a total of 105 abstracts were presented by 129 registered scientists from 23 countries. They covered a wide array of recent applications of gas geochemistry in the field of Earth and Environmental Sciences. In addition to the major gas components $\left(\mathrm{H}_{2} \mathrm{O}, \mathrm{CO}_{2}, \mathrm{~N}_{2}, \mathrm{CH}_{4}, \mathrm{~S}\right.$, halogens $)$ and trace and rare gases, scientists apply gas isotopic techniques ( $\mathrm{C}, \mathrm{H}, \mathrm{O}, \mathrm{S}, \mathrm{N}$, and noble gases) to characterize the sources of gas/fluid samples and to interpret their degassing and migration behavior. In this respect, noble gases hold a

\footnotetext{
* Corresponding author.
}

special place as their rarity on Earth and chemical inertness have made them unique tracers for physical processes. They have been widely used to constrain Earth evolution and structure; characterizing magma genesis and volcanism in different environments; tracing mantle signatures in non-volcanic areas; and even for earthquake and magma surveillance. Many recent examples of these applications were presented at the ICGG9. Therefore, this is an opportune time to publish a special issue to illustrate some of the recent geochemical applications of noble gas geochemistry, and we are pleased to include a total of twelve peer-reviewed papers in this special issue.

\section{Summary of this special issue}

In the first contribution of this issue, Coltice et al. (2009-this issue) use the present-day mantle abundances of xenon isotopes derived from extinct and extant radioactivities to constrain thermal and magmatic evolution models of the early Earth. They conclude that in Hadean times (the first 700 My after the formation of the Earth) heat could escape at a rate much faster than today, due to a much higher mantle convection rate. Such a high rate of geodynamic activity probably prevented the stabilization of large areas of continental crust. Around $3.8 \mathrm{Ga}$ ago, the convection of the Earth's mantle evolved to a mode more similar to the present-day one. These authors suggest that solid-state convection started later than 50 My after the 
formation of the Earth, which is consistent with proposed ages for the Moon-forming impact.

Kurz et al. (2009-this issue) analyze helium and neon in subaerial mylonites collected in the St. Peter and St. Paul archipelagos (Mid-Atlantic Ridge) and in submarine mylonites sampled at the Southwest Indian Ridge, to understand the behavior of noble gases during mantle deformation. Their results show surprisingly large amounts of mantle helium and neon, and that most of the noble gases in the mylonites are trapped in mineral matrices rather than in fluid or melt inclusions. They also found that mantle gases are preserved in fine-grained mylonites at very high concentrations; they suggest that the most likely mechanism is diffusive trapping within defects at mantle pressures. Based on the relationship between texture and helium abundance in peridotites, they suggest that mantle deformation and metamorphism can be an important process controlling the noble gas contents of the crust and the upper mantle.

Czuppon et al. (2009-this issue) report unexpected mid-ocean ridge basalt (MORB) -like noble gas elemental and isotopic compositions in a suite of fresh spinel-peridotite xenoliths from Mt Quincan, North Queensland (Northeast Australia). The absence of any subduction-related noble gas signature precludes the contribution of fluids related to subduction that took place during the Paleozoic at the eastern margin of Australia. Instead, they suggest that the observed MORB-like signature was imprinted during recent fluid entrapment in relation to the rifting tectonic setting of eastern Australia after the Paleozoic subduction events. Any pre-existing subduction signature may have been erased or part of the subcontinental lithospheric mantle physically removed by delamination.

Mohapatra et al. (2009-this issue) present new noble gas and nitrogen isotope data of some oceanic island basalt (OIB) samples and attempt to characterize the geochemical signature of volatile elements in the mantle source of OIBs. They found that their noble gas isotopic data $(\mathrm{He}, \mathrm{Ar}, \mathrm{Xe})$ are consistent with the presence of mantle-derived gases from the OIB source, and a ubiquitous atmospheric component. The isotopic composition of nitrogen and the ${ }^{36} \mathrm{Ar} /{ }^{132} \mathrm{Xe}$ elemental ratio, on the other hand, suggest that the air component is a mixture of air and recycled gases. Their nitrogen isotopic data point to an isotopic component in the OIB mantle with $\delta^{15} \mathrm{~N} \sim-25 \%$, which is distinct from previous estimates. Together with the oxygen isotopic signature of bulk mantle, they further conclude that this component may represent a contribution from volatiles from enstatite chondrite-like materials at the time of the planet's accretion, and may represent pristine nitrogen within the OIB mantle.

Ray et al. (2009-this issue) report new helium and carbon elemental and isotopic data for a suite of hydrothermal gases and fluids from 18 localities in the Central Southern Volcanic Zone (CSVZ) of Chile. Their study shows that the CSVZ of the Chilean Andes is characterized by a wide range of ${ }^{3} \mathrm{He} /{ }^{4} \mathrm{He}, \mathrm{CO}_{2} /{ }^{3} \mathrm{He}$, and $\delta^{13} \mathrm{C}\left(\mathrm{CO}_{2}\right)$ values. Most of the data reflect the effects of crustal processes which act to mask source $\mathrm{He}-\mathrm{CO}_{2}$ characteristics. They conclude that crustal contamination exerts a strong control on the ${ }^{3} \mathrm{He} /{ }^{4} \mathrm{He}$ values in the studied area. They further discuss the parameters which may contribute to the variability observed in the carbon-helium relative abundance and C-isotope systematics.

To verify the origin of anomalously high ${ }^{3} \mathrm{He} /{ }^{4} \mathrm{He}$ ratios (up to $7.13 \mathrm{Ra}$ ) in the Kinki district of southwestern Japan, Sano et al. (2009this issue) collected 25 gas and water samples from hot springs and measured the ${ }^{3} \mathrm{He} /{ }^{4} \mathrm{He}$ and ${ }^{4} \mathrm{He} /{ }^{20} \mathrm{Ne}$ ratios of these samples. They found that the geographical distribution of high ${ }^{3} \mathrm{He} /{ }^{4} \mathrm{He}$ values does not focus on a geographical spot, but defines a region extending parallel to an extinct spreading center in the Shikoku Basin. They suggest that the subducted spreading center might have been a midocean ridge with a transform fault. This hypothesis is apparently supported by seismic tomography, and is consistent with the geometry of the subducting slab deduced from isodepth seismic contours, as well as that of a magnetic anomaly in the region. Therefore, they conclude that the high ${ }^{3} \mathrm{He}$ emanations may trace an extinct ridge-transform-ridge type spreading center in a subduction zone.

Polyak et al. (2009-this issue) report helium isotopic data for $\mathrm{CO}_{2}$-rich springs sampled in the vicinities of the Elbrus and Kazbek active volcanoes, and for $\mathrm{CH}_{4}$-rich gases from mud volcanoes in eastern Georgia. They found that the central segment of the orogen between Elbrus and Kazbek volcanoes differs from its western and eastern segments in that the highest ${ }^{3} \mathrm{He} /{ }^{4} \mathrm{He}$ ratios exceed $3.6 \mathrm{Ra}$. They advocate recent magmatic activity in this region to explain the halo of the elevated ${ }^{3} \mathrm{He} /{ }^{4} \mathrm{He}$ which extends northward, far from the Mt. Elbrus, into the Scythian Plate. Also based on the high ${ }^{3} \mathrm{He} /{ }^{4} \mathrm{He}$ ratios, they call for the presence of hidden magmatic activity near Mt. Kazbek and further to the south, in mud volcanoes of eastern Georgia.

Helium isotopic ratios of modern groundwaters and of fossil fluids trapped in secondary calcites from fault planes were measured by Pik and Marty (2009-this issue) along the southern Corinth rift (the most seismically active area in the European Union), in order to investigate the nature of fluids circulating in these fault zones. The observed helium isotopic ratios of modern fluids range from the air composition to moderately radiogenic compositions, whereas fossil fluids display more radiogenic compositions. These authors suggest that the fossil fluids associated with rifting have been trapped deeper in the fault zone, in the absence of significant atmospheric contamination. They note that the absence of a mantle-He signal in the Corinth rift fluids is remarkable for such a tectonic environment, demonstrating that the fault system is not connected at depth with zones where mantle-He might have been trapped, which places constraints on tectonic models for the development of the Corinth rift zone.

Italiano et al. (2009-this issue) present geochemical data showing the existence of active degassing over a large seismicallyactive sector of the southern Alps (Friuli Region, NE Italy). The chemical composition of the dissolved gases show that a $\mathrm{CO}_{2}$-rich gas phase feeds local groundwaters and that the observed ${ }^{3} \mathrm{He} /{ }^{4} \mathrm{He}$ ratios result from mixing between radiogenic and atmospheric helium, without evidence for the presence of a mantle $\mathrm{He}$ component. The authors also performed a soil gas survey over the area that generated destructive seismic sequences, to characterize $\mathrm{CO}_{2}$ degassing in the studied area. Results of this survey show that a significant amount of crustal gases were released in the continental area of the south-eastern Alps. The lack of ${ }^{3} \mathrm{He}$ prohibits significant mantle contribution to degassing, and these authors propose that $\mathrm{CO}_{2}$ is produced by thermo-mechanical processes occurring at seismogenic depths.

Hu et al. (2009-this issue) report He and Ar isotope data of fluid inclusions in pyrites and $\mathrm{C}$ isotope data of calcites associated with uranium mineralization (pitchblende) in the Xiangshan ore, the largest hydrothermal U-deposit in China. He isotopic compositions range between 0.1 and $2.0 \mathrm{Ra}$ and correlate with ${ }^{40} \mathrm{Ar} /{ }^{36} \mathrm{Ar}$ ratios. These authors suggest that the relatively high ${ }^{3} \mathrm{He} /{ }^{4} \mathrm{He}$ ratios represent a contribution of mantle-derived gases. A mantle origin for volatile elements is also consistent with the $\delta^{13} \mathrm{C}$ values of calcites, which vary from $-3.5 \%$ o to $-7.7 \%$, overlapping with the range of mantle $\mathrm{CO}_{2}$. The authors propose a two-component, i.e., ${ }^{3} \mathrm{He}-$ and $\mathrm{CO}_{2}-$ rich mantle-derived fluids and $\mathrm{CO}_{2}$-poor meteoric fluids, mixing model to explain the observed $\mathrm{He}, \mathrm{Ar}$ and $\mathrm{CO}_{2}$ characteristics of the ore-forming fluids.

In order to test whether rapid fault movement can reset the noble gas isotope ratios of fault rocks, Sato et al. (2009-this issue) performed a high temperature frictional melting experiment on fine grained homogeneous gabbros. The anticipated rapid equilibration of volatiles during the frictional melting of rocks implies that the noble gas isotope composition/ratio was reset to an atmospheric value during the experiment. They measured noble gas isotopes in a gabbro 
sample using laser fusion analysis and found that the resetting of noble gases can only be observed in glass that was completely melted. They also found that the apparent increases in the $\mathrm{K}-\mathrm{Ar}$ ages were only observed in a narrow, $3 \mathrm{~mm}$-wide zone around the fault plane, which appeared in thin section to be thermally altered and mechanically fractured. Therefore, the authors conclude that $\mathrm{K}-\mathrm{Ar}$ ages of fault activity can be quantitatively obtained from the analysis of pseudotachylites (the glassy material at fault zone).

Argon has proven to be one of the most useful elements in understanding the timing and duration of geological processes. Because of its chemical and physical properties, Ar is a particularly sensitive indicator of temperature variations associated with largescale geological events. In the final contribution of this special issue, Lee (2009-this issue) gives a review of using argon as a temporal tracer of large-scale geologic processes. He concludes that the versatility of the ${ }^{40} \mathrm{Ar} /{ }^{39} \mathrm{Ar}$ dating method combined with the effective application of various techniques (e.g. laser spot-dating and stepheating) and a detailed understanding of the diffusion behavior of $\mathrm{Ar}$ has proven to be a powerful research tool in elucidating the timing and duration of many large-scale earth-system processes.

\section{Acknowledgements}

The guest editors would like to thank all authors who have contributed to this special issue. We are also grateful to all reviewers for providing critical and constructive comments/suggestions that improved the manuscripts. Editor-in-chief Bernard Bourdon and the technical editors of the journal, Tim Horscroft and Peggy Tan, are thanked for supporting this special issue. The National Science Council, National Taiwan University and the National Center for Research on Earthquake Engineering of Taiwan provided the funds to organize the 9th ICGG.

\section{References}

Boschi, E., Italiano, F., Martinelli, G., 2007. Preface: Fluids and tectonics. Annals of Geophysics 50 (4), V-IX.

Coltice, N., Marty, B., Yokochi, R., 2009. Xenon isotope constraints on the therma evolution of the early Earth. Chemical Geology 266 (1-2), 4-9 (this issue).
Czuppon, Gy, Matsumoto, T, Handler, M Matsuda, J, 2009. Noble gas in spinel peridotite xenoliths from Mt. Quincan, North Queensland, Australia: Undisturbed MORB-type noble gases in the subcontinental lithospheric mantle. Chemical Geology 266 (1-2), 19-28 (this issue).

Heinicke, J., Martinelli, G., 2005. Preface: A historical overview. Annals of Geophysics 48 (1), V-VIII.

Hu, R.-Z., Burnard, P.G., Bi, X.-W., Zhou, M.-F., Peng, J.-T., Su, W.-C., Zhao, J.-H., 2009. Mantle-derived gaseous components in ore-forming fluids of the Xiangshan uranium deposit, Jiangxi province, China: Evidence from $\mathrm{He}, \mathrm{Ar}$, and $\mathrm{C}$ isotopes. Chemical Geology 266 (1-2), 86-95 (this issue).

Italiano, F., D'Alessandro, W., Martelli, M., 2007. Gas geochemistry as a tool to investigate the Earth's degassing through volcanic and seismic areas: The soul of the 8th International Conference on Gas Geochemistry. Journal of Volcanology and Geothermal Research 165, 1-4.

Italiano, F, Bonfanti, P., Ditta, M., Petrini, R., Sleijko, F, 2009. Helium and carbon isotopes in the dissolved gases of Friuli region (NE Italy): Geochemical evidence of $\mathrm{CO}_{2}$, production and degassing over a seismically active area. Chemical Geology 266 (1-2), 76-85 (this issue).

Kurz, M.D., Warren, J.M., Curtice, J., 2009. Mantle deformation and noble gases: Helium and neon in oceanic mylonites. Chemical Geology 266 (1-2), 10-18 (this issue).

Lee, J.K.W., 2009. Using argon as a temporal tracer of large-scale geologic processes. Chemical Geology 266 (1-2), 104-112 (this issue).

Mohapatra, R.K., Harrison, D., Ott, U., Gilmour, J.D., Trieloff, M., 2009. Noble gas and nitrogen isotopic components in oceanic island basalts. Chemical Geology 266 (1-2), 29-37 (this issue).

Pik, R., Marty, B., 2009. Helium isotopic signature of modern and fossil fluids associated with the Corinth Rift fault zone (Greece): Implication for fault connectivity in the lower crust. Chemical Geology 266 (1-2), 67-75 (this issue).

Polyak, B.G., Lavrushin, V.Y., Kamensky, I.L., 2009. Mantle helium traces in the ElbrusKazbek sector of the Greater Caucasus and adjacent areas. Chemical Geology 266 (1-2), 57-66 (this issue).

Ray, M.C., Hilton, D.R., Munoz, J., Fischer, T.P., Shaw, A.M., 2009. The effects of volatile recycling, degassing and crustal contamination on the helium and carbon geochemistry of hydrothermal fluids from the Southern Volcanic Zone of Chile. Chemical Geology 266 (1-2), 38-49 (this issue).

Sano, Y., Kameda, A., Takahata, N., Yamamoto, J., Nakajima, J., 2009. Tracing extinct spreading center in SW Japan by helium-3 emanation. Chemical Geology 266 (1-2), 50-56 (this issue).

Sato, K., Kumagai, H., Hirose, T., Tamura, H., Mizoguchi, K., Shimamoto, T., 2009. Experimental study for noble gas release and exchange under high-speed frictional melting. Chemical Geology 266 (1-2), 96-103 (this issue).

Yang, T.F., 2008. Recent progress in the application of gas geochemistry: examples from Taiwan and the 9th International Gas Geochemistry Conference. Geofluids 8, 219-229.

Yang, T.F., Italiano, F., Heinicke, J., 2005. Special issue on recent progress in gas geochemistry - Preface. Geochemical Journal 39, 395. 